\title{
MODELLING THE AUSTRALIAN PROPERTY INVESTMENT UNIVERSE: A PRELIMINARY STUDY
}

\author{
DAVID HIGGINS \\ University of Technology, Sydney
}

\section{ABSTRACT}

The benefits of measuring the Australian property investment universe are highly significant. The information can provide the basis for property asset allocation, be a key measure of a nation's wealth and indicate property market opportunities for institutional investors. This research examined three property universe models, each measuring a different component of the Australian property investment market at a specific point of time. Linked together with overseas comparisons, these models provided an outline of the Australian property investment universe. As at December 2003, the Australian property investment universe is estimated to be approximately $\$ 332$ billion, with a core property market (office, retail and industrial) of \$154 billion. However, with institutions owning $\$ 104$ billion of Australian properties (PIR 2003) and applying overseas research on comparing property investment markets to invested institutional property markets, the findings tended to support the suggested Australian property investment universe figures.

Keywords: Property market size, performance analysis, asset allocation, commercial property

\section{INTRODUCTION}

Professionals have long sought methods to accurately measure investment markets of competing asset classes. Alongside risk, return and liquidity, determining market size represents an important strategic benchmark in the asset allocation process. In most bond and equity markets, the value of each security is known, as public trading provides constant pricing information and the number of shares (or bonds) is a matter of public record. On the other hand, the property investment market is fragmented with no central trading place, a variety of ownership structures and a range of different building categories. Less-than-accurate knowledge of the property investment universe is a distinct disadvantage to the property investment community as compared to the better informed alternative asset classes. This can only add to an additional risk premium when developing major property strategies. 
In acknowledging the significance to assess the size of the Australian property investment universe, many in the Australian property industry depend on anecdotal evidence to determine overall property market size. The approximate value placed on a speculative view is in contrast to the portrayed sophisticated approach to property investment in the Australian capital markets. Property researchers from leading international property organisations (for example: DB Real Estate 2002, Henderson Investors 2000, Liang \& Gordon 2003, McIntosh et al 2004 and Whitaker 2001) have undertaken research in this area and have adopted an economic activity (gross domestic product) based approach to estimate the value of a country's property investment market. This top down method can be compared to a bottom up approach, developed from information on a sample location and property data sourced from the Australian property industry as at a specific point of time.

This paper aims to examine and evaluate different methods to measuring the Australian property investment universe. The theory behind the models will be reviewed and model outcomes compared. On several points, there are assumptions, which will be discussed. However, further research is required in key areas and therefore all figures cited should be treated with appropriate caution. Nevertheless, the more knowledge gained on the Australian property investment universe, the better the platform for future commercial property analysis which should ultimately advance the quality of commercial property investment and development decisions for all property investors.

Following the abstract and introduction, Section three explains the benefits of measuring the property universe, with Section four detailing the selected property universe models. Section five discusses the empirical findings from the Australian property universe models and the final section provides concluding comments.

\section{BENEFITS OF MEASURING THE PROPERTY UNIVERSE}

Apart from being able to clearly quantify property as a major asset class, the benefits of measuring the property investment universe are significant. Foremost, it can provide the basis for property allocation, as in many locations, the application of asset pricing models are handicapped by limited quantity and poor quality of property performance data. For an alternative approach, McIntosh et al (2004) discussed a European property portfolio utilising a country's property market size as a base allocation benchmark and then over and underweight according to market expectations.

Similarly, being able to assess the overall size of a property investment market can be a valuable tool for local property professionals, who can compare the property investment universe with the known invested property market as owned by institutions etc. The difference between the two figures would indicate the estimated value of private and corporate-owned property and represent a major source of future property investment for institutional investors (Henderson Investors 2000 and Roulac 2003). 
Investment preferences and debt funding performance can stem from several considerations affected by the property market size. As Smith et al (2004) pointed out, larger markets tend to be deeper markets with more diverse industry sectors. This can provide both a bigger selection of acquisition opportunities and more liquidity for disposal. Likewise, major property markets have smaller supply and demand fluctuations and are less affected by new construction or the downsizing or failure of any single employer. This theme can be extended to debt financing and the probability of loan default. Gordon \& Kizer (2004) research on debt securities illustrated that loans in smaller property markets do demonstrate weaker overall credit performance, even when controlling the debt leverage.

Measuring the property universe can also provide valuable information to government and the property industry. An accurate record of property market size (in dollar terms) can form a key measure of a country's national wealth, alongside demonstrating the role of property as a defined component of the domestic investment universe. Furthermore, property universe data can have an advocacy role for the property industry in examining fiscal policies, such as to illustrate the revenue stream derived by government from property taxes imposed on investment grade properties. (Higgins \& Vamvakoulias, 2004).

\section{PROPERTY UNIVERSE MODELS}

Measuring the size of the Australian property investment market is a challenging task, as some definitions are vague and interpretations do vary among the different property sectors and building grades. In acknowledging the issues and applying broad classifications, property universe models, in principle, do depend on either the relationship with key economic determinants or to known aggregated property data. The three following property universe models utilise these approaches.

\section{Economic Activity Model}

The property investment market of a country should relate to that nation's economic activity (GDP), as property is recognised as an important factor of production. On USA estimates, Liang and McIntosh (1999) constructed a model for developed countries based on the ratio of commercial property to GDP data. For less developed countries (those with a GDP per capita below US\$20,000) having a smaller commercial property market, a formula based on GDP per capita was added.

The Liang and McIntosh (1999) equation is as follows:

Real Estate for Country $y_{i}=G D P_{i} \times\left(\right.$ US Real Estate to GDP Ratio) $\times\left(G D H_{i} / G D H_{u s}\right)^{1 / 3}$

The formula explains real estate as the value of higher-graded commercial real estate, $\mathrm{GDP}_{\mathrm{i}}$ and $\mathrm{GDH}_{\mathrm{i}}$ are, respectively, GDP and GDP per capita for country $\mathrm{i}_{\mathrm{i}}$ To smooth out volatility, Liang and Gordon (2003) applied a four year weighted average to GDP and GDP per capita figures. 
As at December 2003, the calculation for the Australian property investment universe is as follows:

$$
\begin{aligned}
\text { Australian property investment universe } & =45 \% \times \text { AU } \$ 738 \text { billion } \\
& =A U \$ 332 \text { billion }
\end{aligned}
$$

This approach has created considerable interest in the global property research arena, as the size of the global property investment market is now a relatively straightforward calculation. The most recent report by Liang and Gordon (2003) calculated on 2002 GDP values, estimated a global property investment universe of US\$12,479 billion. Table 1 details the top 15 counties by US dollar value and percentage share of the global property investment universe. On Table 1 information, the Australian property investment universe is a relatively small component (approximately 1.3\%) of the global property investment universe.

In addition, the economic activity formula can demonstrate the movement in the property universe over time. For the year to December 2003, the Australian property investment universe grew by $7 \%$, with a five-year annual growth rate of around $6 \%$. 
Table 1: County Concentration of Investment Grade Property

\begin{tabular}{|c|c|c|}
\hline Country & $\begin{array}{l}\text { Estimated Investment } \\
\text { Grade Property (\$USB) }\end{array}$ & $\begin{array}{c}\text { County Share of } \\
\text { Global Property } \\
\text { Investment Universe }\end{array}$ \\
\hline United States & 4,450 & $36 \%$ \\
\hline Japan & 1,915 & $15 \%$ \\
\hline Germany & 872 & $7 \%$ \\
\hline United Kingdom & 830 & $7 \%$ \\
\hline France & 615 & $5 \%$ \\
\hline Italy & 506 & $4 \%$ \\
\hline Canada & 320 & $3 \%$ \\
\hline Spain & 251 & $2 \%$ \\
\hline China & 186 & $2 \%$ \\
\hline Mexico & 182 & $2 \%$ \\
\hline Netherlands & 179 & $1 \%$ \\
\hline Australia & 172 & $1 \%$ \\
\hline South Korea & 157 & $1 \%$ \\
\hline Hong Kong & 147 & $1 \%$ \\
\hline Brazil & 125 & $1 \%$ \\
\hline
\end{tabular}

Source: Liang \& Gordon (2003)

\section{Local Property Market Model}

The size of the Australian property investment market may be gauged by measuring a local property investment market, which displays similar characteristics to the Australian macro economy, for example: proportionally comparable employment figures per industry sector. As part of a wider study (Higgins \& Vamvakoulias, 2004), the Parramatta local government area was selected, as within the council boundaries, there is a broad range of commercial grade properties and leading property companies should have extensive property information due to the council's location within the Sydney metropolitan area. 
Table 2 details the minimum property classification based on Property Council of Australia benchmarks and advice from leading institutional property owners.

\section{Table 2: Investment Grade Property Classification}

\begin{tabular}{lcclc} 
& Land Area & Building Area & Grade & Value \\
\hline Office & - & $>1,000$ sqm & PCA $>$ grade B & $>\$ 5 \mathrm{~m}$ \\
Retail & - & $>5,000$ sqm & PCA categories & $>\$ 5 \mathrm{~m}$ \\
Industrial & $>10,000$ sqm & - & PCA categories & $>\$ 5 \mathrm{~m}$ \\
Misc. & Apply market evidence & & $>\$ 5 \mathrm{~m}$ \\
\hline
\end{tabular}

Source: Author and Property Council of Australia (2004c)

A range of property data was collected from six leading property data providers on a confidential basis. Where available, the current value of individual investment grade properties was determined on the past two years of sale evidence and any recent valuations. In addition, aggregated data from the Property Council of Australia Investment Performance Index detailed the average capital value of the different property sectors. This was applied to the floor area of a property to determine the current property value. The aggregated data detailing the estimated investment grade property market size and value for the Parramatta local government is shown in Table 3.

\section{Table 3:Property Investment Market}

Parramatta Local Government Area - December 2003

\begin{tabular}{lrrc} 
& Building No. & Total Size $(\mathrm{sqm})$ & Value $(\$)$ \\
\hline Office & 122 & 795,000 & $\$ 2,262,000,000$ \\
Retail & 24 & 316,000 & $\$ 1,672,000,000$ \\
Industrial & 80 & $1,120,000$ & $\$ 1,489,000,000$ \\
\hline Total & 226 & $2,231,000$ & $\$ 5,423,000,000$
\end{tabular}

Source: Higgins and Vamvakoulias (2004)

In collecting and analysing the property data, extensive practical property information becomes available. On an aggregate basis, at December 2003, the total value of investment grade property market in Parramatta local government area is $\$ 5.4$ billion and includes by sector; office $42 \%$, retail $31 \%$ and industrial $27 \%$. The main property in 
Parramatta by value is Westfield Parramatta contributing 50\% of the total retail market. The ownership by institutions of Parramatta investment grade property is estimated at 59 buildings with a value of $\$ 2.4$ billion, being $44 \%$ of the property investment market.

On knowing the value of property in the Parramatta local government area, macro economic data on Australia and Parramatta can be compared. After adjustments, the relationship between the macro economic indicators can form the multiplier to derive the estimated size of the Australian property investment universe. Table 4 details this approach based on ABS 2001 Census employment data.

\section{Table 4: Comparison between Australian and Parramatta Employment}

\begin{tabular}{|c|c|c|c|c|c|c|}
\hline \multirow[t]{2}{*}{ Industry sectors } & \multicolumn{2}{|c|}{ Australian } & \multicolumn{2}{|c|}{ Parramatta } & \multirow{2}{*}{$\begin{array}{c}\% \\
\text { difference }\end{array}$} & \multirow[t]{2}{*}{ Adjustments } \\
\hline & No. & $\%$ of total & No. & $\%$ of total & & \\
\hline Manufacturing & $1,010,179$ & $12 \%$ & 11,731 & $14 \%$ & $1 \%$ & \\
\hline Wholesale & $1,896,042$ & $23 \%$ & 5,784 & $7 \%$ & $-16 \%$ & 19,770 \\
\hline Retail trade & $1,211,332$ & $15 \%$ & 9,983 & $12 \%$ & $-3 \%$ & \\
\hline Transport and storage & 355,874 & $4 \%$ & 2,357 & $3 \%$ & $-2 \%$ & \\
\hline Finance and insurance & 312,396 & $4 \%$ & 8,275 & $10 \%$ & $6 \%$ & 3,257 \\
\hline Property and bus. services & 920,331 & $11 \%$ & 10,393 & $12 \%$ & $1 \%$ & \\
\hline Government administration & 307,229 & $4 \%$ & 4,379 & $5 \%$ & $1 \%$ & \\
\hline Sub Total & $6,013,383$ & & 52,902 & & & 61,870 \\
\hline All Industries & $8,298,606$ & & 86,530 & & & \\
\hline
\end{tabular}

Source: ABS (2001)

On examining the employment data by industry sector, the Parramatta local government area employment statistics differed widely in the two sectors of Wholesale, and Finance and Insurance. These sectors were adjusted to the corresponding Australian industry sector percentage. The Australian employment sub-total was divided by the adjusted Parramatta employment sub total to provide a multiplier of 97. This in turn, when applied to the $\$ 5.4$ billion of Parramatta investment grade property provided an estimated Australian property investment universe of $\$ 528$ billion. This well exceeds the economic activity model by $\$ 196$ billion.

For a comparison, on available 1999 to 2001 Australian Tax Office data, the gross income of business entities can provide a realistic measure of economic performance. This is shown in Table 5. 
Table 5: Comparison between Australian and Parramatta Gross Income of Business Entities

\begin{tabular}{|c|c|c|c|c|c|c|}
\hline Industry sectors & \multicolumn{2}{|c|}{ Australian 2000-01 } & \multicolumn{2}{|c|}{ Parramatta 1999-00 } & $\begin{array}{c}\% \\
\text { difference }\end{array}$ & $\begin{array}{r}\text { Adjustments } \\
\$(000,000)\end{array}$ \\
\hline Manufacturing & 253,872 & $18 \%$ & 5,913 & $33 \%$ & $-16 \%$ & 3,138 \\
\hline Wholesale & 229,618 & $16 \%$ & 4,107 & $23 \%$ & $-7 \%$ & 2,839 \\
\hline Retail trade & 159,359 & $11 \%$ & 1,910 & $11 \%$ & $0 \%$ & \\
\hline Transport and storage & 63,526 & $4 \%$ & 694 & $4 \%$ & $1 \%$ & \\
\hline Finance and insurance & 342,721 & $24 \%$ & 665 & $4 \%$ & $20 \%$ & 4,237 \\
\hline Property and bus. services & 101,704 & $7 \%$ & 1,468 & $8 \%$ & $-1 \%$ & \\
\hline Public adm.(education) & 1,362 & $0 \%$ & 6 & $0 \%$ & $0 \%$ & \\
\hline Sub Total & $\overline{1,152,162}$ & & $\overline{14,763}$ & & & $\overline{14,291}$ \\
\hline All Industries & $1,433,412$ & & 17,720 & & & \\
\hline
\end{tabular}

Source: iPLATINUM (2003), ATO (2003)

On applying the same approach as in the employment data analysis, a multiplier of 81 for gross income of business entities can be applied to the $\$ 5.4$ billion of Parramatta investment grade property. This provides an estimated Australian property investment universe of $\$ 437$ billion. This exceeds the economic activity model by $\$ 105$ billion.

\section{Core Property Sector Model}

According to Roulac (2003), the terminology employed for classifying institutional property is in terms of "core" and "non-core" property type. Core property embraces office, retail and industrial markets with non-core representing all other property types, including hotels etc.

The Property Council of Australia, in consultation with the property industry, centrally collect and record the main office markets and Australian retail shopping centres and includes aggregated floor areas. Details on collection, methodology and reporting process can be sourced from the regular Property Council publications (Property Council of Australia 2004a,b). On sourcing the average capital value per square metre from the Property Council of Australia Investment Performance Index, the aggregated value of property sectors can be determined.

The Australian office investment universe representing Grade B properties and above is exhibited in Table 6. 
Table 6 : Australian Office Investment Market: December 2003

\begin{tabular}{lccc}
\hline Grades & Sqm & $\begin{array}{c}\text { Rate } \\
\$ / \text { sqm }\end{array}$ & $\begin{array}{c}\text { Total Value } \\
\$\end{array}$ \\
\hline Prime office & $7,719,000$ & 5,400 & $41,682,600,000$ \\
Grade B office & $6,347,000$ & 3,700 & $23,483,900,000$ \\
Total & $14,066,000$ & 4,550 & $65,166,500,000$ \\
\hline
\end{tabular}

Source: Property Council of Australia (2004a,c)

Table 6 details an Australian office investment universe of $\$ 65$ billion and includes by grades, Prime office $64 \%$ and Grade B office 36\%. The structure of the Property Council Office database allows for the data to be examined by location and building grade.

Similar to the office market, the Australian retail investment universe can be calculated from the Property Council of Australia shopping centre directory. Table 7 displays by grades the shopping centre floor areas and capital values per square metre.

Table 7: Australian Retail Investment Market: December 2003

\begin{tabular}{lcrr}
\hline Grades & Sqm & $\begin{array}{c}\text { Rate } \\
\text { \$/sqm }\end{array}$ & \multicolumn{1}{c}{ Total Value } \\
\hline Major Regional and above & $3,693,000$ & 6,000 & $22,158,000,000$ \\
Regional & $2,217,000$ & 3,600 & $7,981,200,000$ \\
Sub Regional and below & $7,203,000$ & 3,000 & $21,609,000,000$ \\
Misc inc Bulky goods & $1,052,000$ & 2,200 & $2,314,400,000$ \\
\cline { 2 - 4 } Total & $14,165,000$ & 3,700 & $54,062,600,000$ \\
\hline
\end{tabular}

Source: Property Council of Australia $(2004 b, c)$

Table 7 lists the Australian retail investment universe at \$54 billion. The retail market can be segregated by grades, major regional and above $41 \%$, regional $15 \%$, sub regional and below $40 \%$, and miscellaneous including bulky goods $4 \%$.

Overall, there is sound information on the Australian office and retail markets. This is in contrast to the industrial market, with databases limited to specific locations in major metropolitan regions. To overcome this issue, adjusted ABS 2001 census data for industrial employment was applied to Thomson (1997) UK industrial workplace density figures. The derived floor area was adjusted according to Roulac's (2003) specialised/nonspecialised allocation factors (i.e. specialised property has limited value to another organisation, for example: steelworks, and therefore should be excluded from being part of a defined industrial property universe). This total of non-specialised industrial property 
floor space can be in turn subdivided into property investment grade property and secondary property, with the apportionment based on office market ratios.

Table 8: Australian Industrial Employment and Workspace Density: December 2003

\begin{tabular}{lrrr}
\hline Industry Sectors & No. & $\begin{array}{c}\text { Rate } \\
\text { Sqm/person }\end{array}$ & \multicolumn{1}{c}{$\begin{array}{l}\text { Total } \\
\text { sqm }\end{array}$} \\
\hline Manufacturing & 521,000 & 43 & $22,403,000$ \\
Wholesale & 223,500 & 59 & $13,186,500$ \\
Transport and storage & 220,500 & 119 & $26,239,500$ \\
Sub Total & & $61,829,000$ \\
Non Specialised Classification (75\%) & $46,372,000$ \\
Investment Grade Industrial Property (75\%) & $34,779,000$ \\
\hline
\end{tabular}

Source: ABS (2001), Roulac (2003), Thomson (1997)

The industrial floor area estimates should be viewed with caution, as a number of assumptions are made in the approach and the floor area rate is dated and from the UK. A survey of workplace density of Australian industrial occupiers and a further breakdown of the ABS employment figures would provide a better insight into the Australian industrial investment market. On sourced information, the Australian industrial investment universe is detailed in Table 9 .

Table 9: Australian Industrial Investment Market: December 2003

\begin{tabular}{lccc}
\hline Grades & Sqm & $\begin{array}{c}\text { Rate } \\
\$ / \text { sqm }\end{array}$ & $\begin{array}{c}\text { Total Value } \\
\$\end{array}$ \\
\hline Industrial properties & $34,779,000$ & 1,000 & $34,779,000,000$ \\
\hline
\end{tabular}

Source: Property Council of Australia (2004c)

The individual Australian office, retail and industrial investment markets can be combined to provide a total core property sector investment universe (see Table 10). 


\begin{tabular}{lc}
\hline Core Property Sectors & $\begin{array}{c}\text { Total Value } \\
\$ \text { (billion) }\end{array}$ \\
\hline Office & 65 \\
Retail & 54 \\
Industrial & 35 \\
\hline Total & 154 \\
\hline
\end{tabular}

On aggregate, the core property sector universe is approximately $\$ 154$ billion and includes by sector; office $42 \%$, retail $35 \%$ and industrial $23 \%$. This breakdown resembles that portrayed in the Parramatta property investment market: office $42 \%$ retail $31 \%$ and industrial $27 \%$. This information indicates similarities between locations on the composition of the different property sectors.

The core property sector universe is around $46 \%$ of the property universe based on the economic activity model.

\section{DISCUSSION}

The property universe models measure different components of the Australian property investment market and are based on assumptions, with some requiring further research. The estimates should therefore be treated with appropriate care. Nevertheless, the individual models can be examined and analysed in conjunction with relevant overseas research into the relationship between the different property investment market components.

According to Henderson Investors (2000), there are two main estimates which compare the property investment universe with the investment market owned by institutions; one from the UK (Callender and Key, 1996) and the other from the US (PricewaterhouseCoopers and Lend Lease 1999). The research implies grossing up the size of the invested institutional property market by around two and a half to three times. On applying this to PIR (2003) estimates of $\$ 104$ billion held by institutions directly in Australian properties, it would suggest an Australian property universe in the region of $\$ 260$ billion to $\$ 312$ billion. Bearing in mind the UK and US research reports are dated and subsequently there has been an aggressive expansion in the property investment industry, the Australian property investment universe based on the economic activity model of $\$ 332$ billion would be within reasonable limits.

The Roulac (2003) paper on the corporate real estate market suggests that $40 \%$ of aggregated corporate real estate is in core business real estate and would be appropriate for institutional investors. Assuming that core business real estate equates to the core 
property sector, the property universe in terms of the Australia will be approximately $\$ 385$ billion. Interestingly, the institutional ownership of investment grade property in the Parramatta local government area is approximately $44 \%$ of the recorded property investment market, which would translate to an Australian property universe of $\$ 350$ billion. Theses figures would further support the economic activity model for a property universe in the region of $\$ 332$ billion.

The local property market model outcomes provided a clear contrast to the figures from alternative models, although in the two stage local property model, the information on the Parramatta local government property market provided useful information on property composition and ownership structure. The difficulty is in providing a satisfactory measure to compare a local to a national property market. Foremost, the capital values will be too high for the Parramatta properties due to the Sydney metropolitan region location. Similarly, the selected macroeconomic comparables may need to be refined to represent a realistic comparison between a local and national property markets. This research would further benefit from analysis of additional local property markets around Australia. Once information is available, a more comprehensive picture of the Australian property universe can be constructed highlighting opportunities in local property markets compared to national benchmarks.

\section{CONCLUSION}

The benefits of measuring the Australian property universe are significant. The information can provide the basis for property asset allocation, be a key measure of a nation's wealth and indicate property market opportunities for institutional investors. As part of a global property allocation strategy, leading international property researchers have adopted an economic activity based approach to value a country's property investment market. For this research, the popular top down method was compared to a bottom up approach, developed from information on a sample location and to property data sourced from the Australian property industry at a specific point of time.

The three property universe models measure different components of the Australian property investment market. Linked together, they can provide an outline of the Australian property universe. As at December 2003, the models suggest an Australian property investment universe of $\$ 332$ billion with a core property market (office, retail and industrial) of $\$ 154$ billion. The relationship to the $\$ 5.4$ billion property universe of the Parramatta local government area was difficult to substantiate. However, with institutions owning \$104 billion dollars of Australian properties (PIR 2003) and applying overseas research on comparing property investment markets to invested institutional property markets, the findings tended to support the suggested Australian property investment universe figures. 
The property universe research is based on some key assumptions and therefore the estimates should be treated with appropriate caution. More research on the property universe models could have significant practical implications on the Australian property investment market and can include work on a broad property investment grade definition and a defined approach to measuring the Australian industrial investment market. In identifying the limitations of this research, this study does provide a platform for further analysis on the Australian property investment universe.

\section{REFERENCES}

ABS, 2001, Census of Population and Housing: Census Data 2001, Australian Bureau of Statistics, Canberra.

ATO, 2003, Taxation Statistics 2000-01: A Summary of Taxation, Superannuation and Industry Benchmarks, Australian Taxation Office, Canberra.

Callender M \& Key T, 1996, The Total Value of Commercial Property in the United Kingdom, RICS Cutting Edge Conference, London.

DB Real Estate, 2002, A Framework for International Real Estate Investment, Deutsche Bank, Sydney.

Gordon S \& Kizer L, 2004, US CMBS Loan Performance: Impact of Seasoning, Leverage and Location on Probability of Default, Moody's Investors Service, New York.

Henderson Global Investors, 2001, The Global Property Market Risk Premium, Henderson Global Investors, London.

Henderson Investors, 2000, The Case for Global Property Investment, Henderson Investors, London.

Higgins D \& Vamvakoulias D, 2004, Pilot Study of Investment Grade Property:

Parramatta Local Government Area, Unpublished, Property Council of Australia.

iPlatinum, 2003, Enterprising City Outcomes: Establishment of Baselines, Parramatta City Council, Sydney.

Liang Y \& Gordon N, 2003, A Bird's Eye View of Global Real Estate Markets, Prudential Real Estate Investors, New Jersey.

Liang Y \& McIntosh W, 1999, Global Commercial Real Estate, Prudential Real Estate Investors, New Jersey.

McIntosh W, Witalis K \& Whitaker W, 2004, Estimating the European Real Estate Universe, ERES Conference, Milan.

PricewaterhouseCoopers \& Lend Lease, 1999, Emerging Trends in Real Estate 2000, PricewaterhouseCoopers \& Lend Lease, New York. 
Property Council of Australia, 2004a, Australian Office Database, Property Council of Australia, Sydney.

Property Council of Australia, 2004b, Australian Shopping Centre Database, Property Council of Australia, Sydney.

Property Council of Australia, 2004c, Investment Performance Index 2003, Property Council of Australia, Sydney.

PIR, 2003, Australian Property Fund Industry Survey, Property Investment Research, Melbourne.

Roulac S, 2003, Corporate-Owned Real Estate Represents a Substantial Investment Universe, Journal of Real Estate Portfolio Management, Vol.9 No. 2 p167-178.

Smith A, Hess R \& Liang Y, 2004, Size-tiered Economic Geography: A New View of the US Real Estate Markets, Prudential Real Estate Investors, New Jersey.

Thompson R, 1997, Industrial Employment Densities, American Real Estate Society Conference, Sarasota.

Whitaker B, 2001, Why Should Investors Consider International Real Estate Investment?, Global Real Estate Perspective, AIG Global Real Estate Investment Corp, New York. 